\title{
The Dating of Deuteronomy : A Response to Nathan MacDonald
}

\author{
Pakkala, Juha
}

2011

Pakkala , J 2011 , ' The Dating of Deuteronomy : A Response to Nathan MacDonald ' , pÿZeitschrift für die Alttestamentliche Wissenschaft , vol. 123 , no. 3 , pp. 431436 . https://doi.org/10.1515/ZAW.201

http://hdl.handle.net/10138/328054

https://doi.org/10.1515/ZAW.2011.029

unspecified

publishedVersion

Downloaded from Helda, University of Helsinki institutional repository.

This is an electronic reprint of the original article.

This reprint may differ from the original in pagination and typographic detail.

Please cite the original version. 


\title{
The Dating of Deuteronomy: A Response to Nathan MacDonald ${ }^{1}$
}

\author{
Juha Pakkala
}

(Department of Biblical Studies, University of Helsinki, P.O. Box 33, FIN-00014 Helsinki; pakkalajuha@yahoo.de)

I am grateful to Nathan MacDonald for his constructive response »Issues in the Dating of Deuteronomy: A Response to Juha Pakkala " in ZAW 122 (2010), 431-435, to my paper »The Date of the Oldest Edition of Deuteronomy, « published in ZAW 121 (2009), 388-401. Many of the points MacDonald has raised are important and advance the discussion about the dating of Deuteronomy. Since this question is so central to the study of the whole Hebrew Bible, there is no doubt that it should be addressed directly.

One by one, MacDonald looks at my arguments and brings counter-arguments against them, which, he contends, show that the late dating is still not proven. Because none of the arguments are bulletproof, there would not be enough evidence to assume that Deuteronomy derives from a post $586 \mathrm{BCE}$ setting. Although MacDonald's considerations are significant and should certainly be addressed, it must also be pointed out that hardly any theory in Biblical studies (or humanities in general) has ever been proven. I am not convinced that theories concerning the Hebrew Bible can be placed in the scale guilty (true), not proven, and not guilty (not true), because that seems like a demand rising out of empirical sciences. Many of MacDonald's points are excellent, and some of them may even be convincing to the extent that one or two of my arguments may seem uncertain. Anyway, I welcome him to evaluate the cumulative effect of all the considerations, because it is not any single point that makes my case.

MacDonald contends that my approach is via negativa. It is true that some of the arguments are based on the lack of something, and this is always tricky. However, we have a document the dating of which is unclear and we are trying to find its most probable historical setting. If something is missing or contradicts a certain context, it should not go completely unheeded. If the king is missing, it is not a crucial issue, but it has at least to be noted and certainly not ignored. In the case of Deuteronomy all central institutions of the Judean state are missing (the king, temple and state). It would be difficult to ignore this fact, or at least one needs a very good explanation for why they are missing if the document is dated to a time when they should have been present. This approach can be portrayed as via negativa, but I sense that MacDonald takes the $7^{\text {th }}$ century BCE dating as the starting point which has to be proven incorrect, before we can move forward. The $7^{\text {th }}$ century BCE dating is, after all, often based on the connection between Deuteronomy and II Reg 22-23. ${ }^{2}$

1 I am very grateful to Christoph Levin for his important comments and suggestions on this paper.

2 The connection between Deuteronomy and the vassal treaties of Esarhaddon (VTE) has been adequately treated in recent scholarly discussion (most recently C. Koch, Vertrag, Treueid und Bund, BZAW 383, 2008) and need not be repeated here. Some scholars, such as C. Levin, Fortschreibungen, BZAW 316, 2003, 198, assume that the Urdeute- 
MacDonald also points out that Deuteronomy is not straightforwardly a mirror of its moment of composition and that one should »engage the Mosaic presentation of the book « (431). He implies that the pre-state setting of Deuteronomy could explain some of the issues that are missing and that more imaginative seriousness is needed in this enterprise. Instead of imagining possible reasons why a monarchical document was placed in a non-monarchical setting, attention should be concentrated on discussing the Urdeuteronomium itself because the setting and prologue of the book is very likely late. The discussion about the pre-monarchical setting of Deuteronomy is essentially a discussion about the interrelationships of the later stages of the book and is not directly relevant for the dating of the Urdeuteronomium. I will now discuss the numbered points in MacDonald's paper.

First, MacDonald points out that less than five percent of Codex Hammurabi's laws »refer to the king or royal trappings " (432). This is, in fact, a considerable amount, as most of the laws deal with cases of civil law where the king has no function, but this is not the main problem with the lack of reference to the king in Deuteronomy. In Codex Hammurabi the laws are established by the king and are of the king. ${ }^{3}$ The prologue and epilogue of the codex fundamentally legitimate the monarch's power and legal authority over his people. ${ }^{4}$ This is all missing in Deuteronomy, and instead, the younger framing of Deuteronomy seeks to give authority and legitimacy to itself by being a revelation to Moses. The main problem is not the lack of reference to the king in the laws, but the fact that Deuteronomy does not seem to take the king into consideration at all, which, in view of the known Near Eastern laws, would be unimaginable at a time when there was a king in Judah.

Appealing to the imaginative pre-monarchical setting of Deuteronomy, MacDonald implies that Moses could represent the king, but this line is not explored further in his response. In any legal setting, and especially in antiquity, legitimating a certain set of rules or laws would be central to upholding the existing social order led by the royal house. It would undermine the power of the king to present a pre-monarchical hero - a prophet or priest - as the one to whom Yahweh gave the Law and thus also the keys to uphold the social order. The transfer of authority from Moses to the king is lacking in Deuteronomy, which shows that the authors of the Urdeuteronomium and its younger framing did not need to be concerned about the authority and legitimacy of the king. One needs more than imaginative seriousness to draw a line from a non-monarchical hero like Moses to the allegedly present dynasty.

Moreover, much of Deuteronomy deals with issues or events that happen in the place "Yahweh will choose", supposedly Jerusalem if the $7^{\text {th }}$ century BCE dating is accepted. For

ronomium is a pre-586 BCE document even if there were no direct connection with II Reg 22-23.

3 The beginning of the epilogue (column XL) explicitly shows how central the king is to the law: "(These are) the just laws (di-na-a-at mi-ša-ri-im) that Hammurabi, the capable $(l e-u$-um $)$ king, established $(\dot{u}$-ki-in-nu-ma). "I thank Robert Whiting for pointing this out.

4 As noted by B. Levinson, The Reconceptualization of the Kingship in Deuteronomy and the Deuteronomistic History's Transformation of the Torah, VT 51 (2001), 511-534, 511-512, »The Deuteronomic Torah establishes itself as sole sovereign authority, and thus in effect usurps the traditional authority of the monarch." He concludes (p. 534) that this utopian delimitation of royal power never passed from constitutional vision into historical implementation. « Levinson has rightly seen the problem but he tries to find the solution by assuming that Deuteronomy was written before 586 BCE. 
the main feasts the entire nation is ordered to come to Jerusalem, but the author does not give any role to the king in these feasts. Such major feasts with the whole nation involved can hardly take place without the king having a central role.

Acknowledging that it may be a later addition, MacDonald notes that Deut 17,14-20 does mention the king. However, this law only seeks to curb the king's power. It cannot fit into a monarchical setting, and in fact, Deut 17,14-20 would be an excellent argument against a monarchical setting of Deuteronomy, were it not a late addition. The context of the addition may be a later fear that the dynasty retakes power. In an attempt to limit his possible future powers, a later editor made the addition.

Second, concerning the lack of state infrastructure, Deut $16,18-17,12$ is illuminating. These verses refer to local judges and officials that should be appointed in the towns, but their relationship to the central government is puzzling. According to Gertz, the oldest and Deuteronomic text of these verses is found in Deut 16,18aob; 17,8a*b.9a*b.10a.12a*b $\alpha .^{5}$ In difficult judicial cases, instead of any reference to the central government or representative of the king, the judges and officials are ordered to go "to the place that Yahweh will choose " and consult the priest or the local judge there. The priest is mentioned as the first to be consulted and the location to go is defined as a subordinate of the centralization law of Deut 12 . The author of these verses implies that judicial structures are linked to the location of sacrifice and that priests are a central part of these structures. ${ }^{6}$ The priestly nature of the judicial structures underscores the lack of adequate state infrastructure.

MacDonald notes (432f.): »If Urdeuteronomium were composed in the sixth century $\mathrm{BCE}$, there is no reason for these [state structures] to be absent since the hope of a full restoration persisted, whether focused around Jehoiachim, Shealtiel or Zerubbabel. «If Deuteronomy was written as a document for a state that was being planned, one would perhaps expect to find them, but MacDonald seems to exclude the possibility that the book was written mainly to guide religious conduct in a non-state situation. In any case, one cannot avoid the assumption, made by many scholars at least since Hölscher, ${ }^{7}$ that Deuteronomy is a fantastic and unrealistic plan.

Third, in order to explain why Israel is used instead of Judah, MacDonald resorts to speculation about the possible claims of sovereignty that the Judean monarchs may have had over the northern kingdom. We have very little information about the conditions in 7 th century BCE Judah, but more is needed to explain the use of the word "Israel « than possible claims of sovereignty over a state that had disappeared in the $8^{\text {th }}$ century BCE. If one were to try to build on this line, legitimating the Judean dynasty's authority over the Israelite population would be a central issue. Without a reference to the king, any assumption that Deuteronomy had a political aspect is questionable.

Fourth and fifth, MacDonald rightly points out that the Covenant Code as a possible background of Deuteronomy should be taken into consideration. Although alternative sol-

5 J. C. Gertz, Die Gerichtsorganisation Israels im deuteronomischen Gesetz, FRLANT 165, 1994, 33-41.71.

6 Gertz, Gerichtsorganisation, 116.226-227, argues that the Deuteronomic author intended to professionalize and harmonize the judicial practices and structures throughout the country using the capital as the model.

7 G. Hölscher, Komposition und Ursprung des Deuteronomiums, ZAW 40 (1922), $161-255,183-186$. 
utions have been offered, ${ }^{8}$ Deuteronomy may be dependent on the Covenant Code (or its early version, or a document similar or related to it) when emphasizing the word māqôm. This does not mean, however, that one could not say that the māqôm is the temple in Jerusalem. If Moses was able to see that Israel will be their land, why would he not be able to see that Jerusalem is going to be their capital and its temple their cultic center? Of course, the lack of reference to the temple and Jerusalem leaves room for speculation, but it should be emphasized that we are dealing with probabilities. My contention is that the lack of reference to the temple and Jerusalem implies a complicated and uncertain historical setting where the author may have had to avoid direct references to Jerusalem and its temple.

Sixth, my main point was that Deuteronomy is vague and lacks references to Judah and its inhabitants. MacDonald argues that Deuteronomy uses the word »tribe " only as a societal unit. However, the use of the expression »one of your tribes « implies that the author saw Israel as consisting of several tribes. Since the author chose to express the state as consisting of tribes rather than administrative units of the state (such as in I Reg 4,7-19), the setting of Deuteronomy is probably a faith community that is construed to consist of tribes and which is called Israel. This undermines Judah as a state, and would fit poorly to 7 th century BCE Judah.

Seventh, MacDonald appeals to the Mosaic presentation where the imperfect form would be appropriate, but he fails to engage the problem that the setting we have is secondary. That the future speech hangs in the air in the reconstructed Urdeuteronomium is a wider problem that may imply that parts of Deuteronomy were rewritten ${ }^{9}$ to suit its present context in the Pentateuch.

Eighth, Veijola is not alone in leaving Deut 12,21 in the oldest edition of the book. ${ }^{10}$ MacDonald invests much space to show that Veijola's position on Deut 12,21 is improbable, but one should also note that the same reference to »the place that Yahweh sets his name to live in « is also found in Deut 14,23;16,2.6.11, which are more commonly accepted as part of the Urdeuteronomium. ${ }^{11}$

8 For example, Levin, Fortschreibungen, 97-101, has suggested that Ex 20,24b, which is relevant here, is dependent on Deut 12. According to him, the addition was made in order to accommodate the new situation of the Diaspora.

9 Cf. N. Lohfink, Fortschreibung? Zur Technik von Rechtsrevisionen im deuteronomischen Bereich, in: T. Veijola (ed.), Das Deuteronomium und seine Querbeziehungen, SESJ 62, 1996, 127-171, 142-148.

10 Thus also, for example, A. F. Puukko, Deuteronomium, 292 (see also p. 230-235 where he presents views of many others before him); C. Steuernagel, Lehrbuch der Einleitung in das Alte Testament, 1912, 188 and O. Kaiser, Einleitung in das Alte Testament, 1969, 110. G. Braulik, Deuteronomium 1-16,17, NEB.AT 15, 1986, 100, assumes that Deut 12,21 derives from the last years of Josiah's reign. Similarly also H. D. Preuss, Deuteronomium, 1982, 51, who assumes that the verse is one of the early deuteronomic additions.

11 Thus A. Bertholet, Deuteronomium, KHC 5, 1899, XIX; Puukko, Deuteronomium, 292-295; G. Seitz, Redaktionsgeschichtliche Studien zum Deuteronomium, BWANT 93, 1971, 281 (on Deut 14,23) and many others. Nevertheless, M. Keller, Untersuchungen zur deuteronomisch-deuteronomistischen Namenstheologie, BBB 105, 54-58, assumes that only the reference to the place (לשכן את שמי שם) is a separate addition in Deut 14,$23 ; 16,2.6 .11$, but it would be very speculative to take out just one phrase on thematic grounds. Keller rightly argues that the shem-theology may be a post $586 \mathrm{BCE}$ 
Ninth, MacDonald points out that the Elephantine correspondence raises many questions, and it is true that the implications of the temple in Elephantine for Deuteronomy are complicated. One cannot make direct conclusions from Elephantine to Deuteronomy. However, the good questions raised by MacDonald do not diminish the problem that Elephantine papyri cause for the $7^{\text {th }}$ century BCE dating. Since we are dealing with probabilities, the Elephantine correspondence shakes the traditional conception that Deuteronomy's rise began already in the $7^{\text {th }}$ century BCE. Instead of trying to water down the importance of Elephantine correspondence by appealing to the uncertainties about the nature of the community, one should rather try evaluate whether the evidence from Elephantine fits the $7^{\text {th }}$ century BCE dating of Deuteronomy or favors a later dating.

Tenth, MacDonald presents my approach as either-or and rightly notes that "ancient writers seem quite capable of thinking about the past by means of analogy « (434), but I do not fully understand how this point is relevant here. My argument appeals to the unrealistic nature of Deut $12,13-14 ; 14,22-26$ and $16,1-17$, where a projection to the past plays no significant role. They are orders to Israelites to come to the central sanctuary for all cultic slaughter and feasts. That the Tabernacle stories should not be taken literarily is evident, but the importance of the Tabernacle in many parts of the Pentateuch may be a mirror of an age when there was no temple and when its priests were in the "desert" of the exile.

To sum up, even if the Scottish law allows the jury to give a verdict not proven (which has been criticized at least since the early $19^{\text {th }}$ century), it is not a viable option in Biblical Studies. In order to make progress, we should discuss which theories are more probable and which are less probable. Expecting a case completely proven would lead nowhere and would, in practice, mean adherence to old theories, and in the worst cases adherence to conceptions presented by authors of the Hebrew Bible. For the sake of fairness, one should also evaluate the conventional theory that Deuteronomy derives from the $7^{\text {th }}$ century BCE or from another monarchical setting. With the same logic and approach as taken by MacDonald, one would certainly come to the same conclusion that the monarchical context of Deuteronomy is not proven. Having then two possibilities that are both not proven, we should take the next step and evaluate which one of the not proven theories is more probable. Being grateful for his response, I greatly encourage Nathan MacDonald to take this step as well.

MacDonald (in ZAW 122/3) has brought important counter-arguments against my earlier paper on the dating of Deuteronomy (ZAW 121/3). He contends that the late dating is still not proven, implying that definite proof is needed, but this is an unrealistic goal in the human sciences. In addition to addressing MacDonald's counter-arguments and showing that most of them are problematical, my response emphasizes the cumulative effect of all considerations, which clearly favors a late dating. The response also calls for a discussion of the conventional monarchical dating. With the same logic and approach as taken by MacDonald, one would certainly come to the same conclusion that the monarchical context of Deuteronomy is not proven. The response encourages MacDonald to take the next step and evaluate which dating, monarchical or non-monarchical, is more probable.

attempt to understand the presence of Yahweh after his temple was destroyed (p. 153-170.206), but because he is bound by the monarchical dating of Deuteronomy, he has to take all references to Yahweh's name out of the Urdeuteronomium. 
MacDonald (in ZAW 122/3) a présenté d'importantes critiques de mon étude précédente sur la datation du Deutéronome (ZAW 121/3), contestant la valeur d'une datation tardive - de toute manière, la notion d'une preuve définitive étant illusoire en sciences humaines. Dans cette réponse, les contre-arguments de MacDonald sont discutés, la plupart d'entre eux se révélant problématiques; par ailleurs, la valeur cumulative de mes arguments en faveur d'une datation tardive semble favorisée à l'évidence. MacDonald devrait également discuter la datation conventionnelle à l'époque monarchique tardive: selon les mêmes présupposés et les mêmes arguments, on en viendrait à la conclusion que la datation du Deutéronome à l'époque monarchique tardive n'est pas établie! Il appartient maintenant à MacDonald de faire un pas de plus et d'établir quelle datation, durant ou après l'époque monarchique, est la plus vraisemblable.

MacDonald (in ZAW 122/3) hat wichtige Gegenargumente zu meinem früheren Artikel über die Datierung des Deuteronomiums (ZAW 121/3) gebracht. Er behauptet, dass die späte Datierung nicht bewiesen ist. Eindeutige Beweise beizubringen, ist aber ein unrealistisches Ziel in den Geisteswissenschaften. In meiner Antwort werden die Gegenargumente von MacDonald diskutiert und gezeigt, dass die meisten seiner Argumente problematisch sind. In meiner Antwort betone ich vor allem die kumulative Wirkung aller Überlegungen, durch die die Spätdatierung eindeutig favorisiert wird. MacDonald sollte auch die konventionelle Datierung in der späten Königszeit diskutieren. Mit der gleichen Logik und dem gleichen Ansatz von MacDonald, würde man ebenfalls zu dem Schluss kommen, dass die Datierung des Deuteronomiums in die späte Königszeit nicht bewiesen ist. Daher wird MacDonald aufgefordert, den nächsten Schritt zu tun und zu bewerten, welche Datierung, in oder nach der Königszeit, die wahrscheinlichere ist. 